\title{
Non-Western Model of Civil Society in the Middle Eastern Context: Promises and Discontents
}

Pavel V. Shlykov

\author{
Pavel V. Shlykov \\ Lomonosov Moscow State University, Russia \\ Institute of Asian and African Studies \\ Department of Middle Eastern Studies \\ Associate Professor; \\ Institute of Scientific Information for Social Sciences (INION RAN), Moscow, Russia \\ Department of Asia \\ Senior Research Fellow \\ ResearcherID: N-3826-2014 \\ Scopus Author ID: 57194032891 \\ ORCID: 0000-0002-0331-430X \\ E-mail: shlykov@iaas.msu.ru \\ Address: Institute of Asian and African Studies, Lomonosov Moscow State University, \\ 11 Mokhovaya Str., Moscow 125009, Russia
}

DOI: $10.31278 / 1810-6374-2021-19-2-134-162$

\section{Abstract}

The article analyzes the specific experience of civil society development in the Middle East, which remarkably exposes the dilemma underlying the civil society concept as a matrix of working democracy. This concept limits the understanding of the very phenomenon of civil society and peculiarities of its functioning in the region. An analysis of the Middle Eastern specifics requires a functional approach and a hybrid definition of civil society. This approach has a number of heuristic advantages over both liberal and critical theories. The article outlines the Middle Eastern model of civil 
society and postulates the key characteristic of illiberal civil society-it becomes conducive to the reproduction of authoritarian regimes even despite its institutional diversity. The analysis shows the ambivalence of civil society in the Middle East as a space of limited freedom of political/ non-political activity and as a testing ground for the development of various tools designed to curb civic initiative. The liberal model of civil society, directly incorporated in state-building, is turned upside down in the Middle East. Civil society organizations in this region are hardly functional as an outpost for promoting liberal democratic values because they prove to serve the interests of the elite or alternative political forces much more than the interests of ordinary citizens.

Keywords: Middle East, Turkey, non-Western civil society, illiberal democracy, civil society organizations, hybrid regimes.

ttention to and support for civil society has long been an
integral part of efforts to promote democratic values in the non-
Western world in general and in the Middle East in particular. At the same time, the dominant liberal discourse implying a direct correlation between the activity of civil society institutions and the level of democracy (Putnam, 1993; Diamond, 1994; Edwards and Foley, 1996; Rosenblum and Post, 2002; Toepler and Salamon, 2003) distorts and even reduces the civil society concept. A detailed analysis of civic engagement in Turkey and a number of Arab countries in the regionlarge, like Egypt, or small, like Jordan and Lebanon (Wiktorowicz, 2000; Cavatorta and Durac, 2010; Altan-Olcay and İçduygu, 2012; Çakmak, 2017) - shows the fallacy of attempts to extrapolate the experience of Central and Eastern European countries, where the "development of civil society equals democracy" formula has justified itself.

The regional specificity of the Middle East clearly exposes the dilemma that underlies the concept of civil society as a matrix of working democracy. For all its attractiveness, it limits the understanding of both the very phenomenon of civil society and the peculiarities of its functioning in countries with hybrid regimes, where civil society and its institutions may not facilitate the development of 
democracy, but instead may be used in the opposite way, that is, as $\boldsymbol{a}$ tool with which authoritarian rulers consolidate their power, and the ruling elites practice new forms of dominance.

The idealization of civil society as a universal means of building democracy is not entirely justified because civic engagement is ambivalent in nature and because, as Augustus Norton rightly pointed out in the early 1990s in his introduction to "Civil Society in the Middle East," freedom of action often does not arouse enthusiasm, but evokes serious concerns (Norton, 1995). One can say that over the three decades since the publication of this book those concerns proved justified: there are increasingly deep divisions in Middle Eastern societies recorded by researchers, the growing destructive influence of non-state actors, and the intervention of external arbitrators with controversial consequences (Naumkin, 2015; Baranovskiy et al., 2018).

At the same time, as this article argues, in many countries of the region, civil society has certain peculiarities:

- It is characterized by structural complexity and an impressive scope of social action;

- It has the capability of accommodating Western influence;

- It shows an amazing ability to adjust to fluctuations of political regimes, which allows it to camouflage and maintain its own grassroots network activity.

The first section of this article provides a brief overview of contemporary civil society theories and shows the limits of a liberal civil society model for the Middle East. Its specificity requires a functional approach to analysis and a hybrid definition of civil society, which has a number of heuristic advantages over both liberal and critical theories.

The second section, based on the functional approach, outlines the Middle Eastern model of civil society and postulates a key characteristic of illiberal civil society, which, even despite its impressive statistical size and institutional diversity, essentially facilitates the reproduction of authoritarianism. Under hybrid political regimes, civil society actually becomes a captive of the state. 
The third section analyzes the specific features of subordination, deterrence, and control mechanisms, with a focus on Turkey as the most Westernized state of the region and at the same time a country of classical competitive authoritarianism. The analysis of empirical material provides an opportunity to see the obvious ambivalence of civil society in the Middle East, which is both a space of limited freedom of political and non-political activity, and a testing ground for the development of various tools designed to curb civic initiative.

The final section analyzes mechanisms of external manipulation of civil society by international organizations and extra-regional players, which does not lead to its liberalization, but exacerbates social divisions and increases fragmentation.

\section{CONCEPTUAL UNDERSTANDING OF CIVIL SOCIETY}

Although conceived a long time ago, the civil society concept remains debatable. Modern academic literature distinguishes two main approaches towards analyzing this phenomenon. They can be tentatively classified as "liberal" and "critical." The former defines civil society as a sphere where individual rights and freedoms are exercised without direct intervention of the state (Cohen and Arato, 1992, pp. 29-30). Its main institutions, according to the liberal theory, are voluntary, autonomous and self-regulating organizations of various kinds, such as associations, foundations, NGOs, trade unions, religious groups, and social movements (Diamond, 1994). The liberal theory postulates a direct relationship between civil society and the level of democracy, since civic activism opposes undemocratic order and helps mobilize society to counter authoritarian trends (Foley and Edwards, 1996; Rosenblum and Post, 2002). The liberal model of civil society gives it a key role in deterring potential abuses, ensuring accountability of the government, and building feedback between the state and society by encouraging a culture of political engagement and democratic pluralism (Putnam, 1993).

Assertions regarding the key role of NGOs and civil society in the liberalization and consolidation of democracy have a long history and can be traced back to the first half of the 19th century, for example 
in Alexis de Tocqueville's works (2000). Classics of modern political science Gabrielle Almond and Sydney Verba (1963) also supported the idea of a direct connection between the development of civic culture and the expansion of liberal democracy. Robert Putnam (1993) proved this relationship in his book Making Democracy Work. Using modern Italy as an example, he showed a direct connection between the level of socioeconomic development of regions and the number of public organizations in them. Another well-known modern democracy theorist, Larry Diamond, examined the correlation between civic participation and the transformation of democratic structures, and came to the conclusion that in most cases civil society not only served as a matrix for building a democratic political system, but also provided a universal tool for ensuring the effectiveness of democracy (Diamond, 1994).

Critics of neo-Tocquevillian approaches to civil society and democracy draw attention to the broad range of civic engagement activities and mechanisms employed by public associations, depending on the regional socio-cultural and political context (Edwards, 2014). Researchers who disagree with the paradigm advocated by Putnam and Diamond argue that civil society is not a single entity but consists of different social forces which are struggling among themselves and are often unable to come to agreement (Tarrow, 1996). Furthermore, policies stimulating the development of civil society in non-Western countries sometimes lead to situations where civil society infrastructure is used to achieve destructive goals and objectives that are a far cry from the humanitarian ideals honored by liberal democracy and civil society (Baranovskiy et al., 2018, p. 188).

The advocates of the critical approach reject the thesis that civil society can be autonomous and self-regulating, claiming that it cannot be completely independent from the state (Chandhoke, 2001), because it is the state that determines the rules of the game, and civil society has to act within the administrative and legal limits established by the state (Buttigieg, 2005). They also question the a priori democratic nature of civic engagement, since authoritarian regimes often exploit civil society in their own interests (Wiktorowicz, 2000; Lewis, 2013). At the same 
time, the conflict potential inherent in civil society exacerbates social divisions and fragmentation of civil society, and the system of patronclient relationship characteristic of authoritarian regimes turn civil society into a vertically structured hierarchy. In hybrid regimes that combine elements of democracy and authoritarianism, civil society can even act as an instrument for retaining power and consolidating "undemocratic order," allowing the government to use it as a feedback channel for targeted work with the electorate.

The point in this discussion is that the connection between the development of civil society and democratization should not be taken as a normative axiom. In some countries, this formula really works, in others, it most obviously fails. Civil society is essentially an indicator showing the complexity of political process in each individual country.

As a result, the analysis of civil society in a non-Western political context requires a functional or hybrid definition of civil society, combining the conceptual elements of both liberal and critical approaches, and its interpretation as an "arena for argument and deliberation, as well as for association and institutional collaboration" (Edwards, 2005; Edwards, 2014, pp. 116-117). This underlines the diversity of its institutional forms and actors that differ by the degree of formalization, autonomy and influence (Buttigieg, 2005). So civil society is a sphere of both civic activism and interaction between the state/authorities and organized social forces, within the framework of which the balance of power is determined by the capabilities of the ruling regime and the possibilities of the opposing social groups. Since the nature, forms and extent of this interaction are changeable, the boundaries of civil society are very relative and flexible. As a sphere of action, civil society is formed by a variety of NGOs, associations, women's organizations, social movements, and groups. None of them is immediately subordinated to the state, part of political institutions, or directly linked to the ruling party, power structures or bureaucratic apparatus, but nor are they isolated from them either, and come under their influence one way or another.

The functional approach to civil society has at least three heuristic advantages over the liberal and critical models. 
Firstly, it makes it possible to draw a correlation between the nature of the political regime in a country and the specifics of civic activism. The nature of the political regime not only sets the legal framework for civil society, but also largely determines relations within civil society and the nature of its opposition to the state, which varies in countries with hybrid regimes from confrontation to a patron-client relationship.

Secondly, it is based on the heterogeneity of civil society, some segments of which can be used by authoritarian regimes as an instrument for strengthening their power. By manipulating civil society, the government can use social structures to propagate the "right discourse" and curb public criticism of its actions (Lewis, 2013).

Thirdly, the functional approach provides the most flexible way of defining the main actors of civil society, while avoiding blind association of some specific types of public organizations with it and staying away from statistical determinism in assessing civil society.

Researchers studying civil society in countries with hybrid regimes thus get a chance to identify crucial peculiarities-forced exclusion of certain social groups from civil society and incorporation of pro-regime NGOs into it (Carothers, 2014), mechanisms employed by individual structures to enter or exit civil society (Muthiah, 2004) — and show both mechanisms simulating civil society in its liberal interpretation, and a variety of specific forms and historical peculiarities of citizen activism in the Middle East.

Applied to the Middle Eastern context, the functional approach shows how regulatory, political, institutional, and discursive factors not only restrain the development of civil society, but also transform it, neutralizing civic activism and subordinating it to the interests of the ruling regime. Also, this approach can show different ways of civil society's adaptation to hybrid regimes through the diversification of civic engagement instruments, fragmentation of civil society or its actual seizure by the state. In different countries of the region-Westernized like Turkey, more traditional like Saudi Arabia, large like Egypt, or small like Jordan and Lebanon-one can see a combination of both encouragement and punishment, as well as the development of mechanisms for building compromise-based interaction between political and civil societies. 


\section{OUTLINES OF THE MIDDLE EAST'S SPECIFICITY: CIVIL SOCIETY AND ITS MAIN INSTITUTIONS}

Empirical material of the Middle East clearly exposes the limits of the widespread view on civil society as an essential tool for dismantling authoritarian regimes and building democracy. It also shows the analytical flaws of the linear interpretation of democratization as a natural process, a sufficient condition for which is the existence of civil liberties and active NGOs.

A classic example is a variety of Islamic movements, which are widespread and quite influential in the Middle East. They tend to have well-established mechanisms for mobilizing their supporters and often act outside direct state control, that is, they fully meet the criteria of "influential civil society actors." At the same time, they do not function as a catalyst of democratization, since for the most part they are allergic to "Western liberalism." There is a paradox: the democratic deficit and the weakness of democratic institutions in the Middle East actually stem from strong civil society, albeit illiberal, which along with the dominance of public organizations dependent on the authorities helps preserve and reproduce authoritarian regimes. There are two extreme points of view explaining this phenomenon: some are convinced that civil society in the region is strong, but undemocratic/ illiberal, while others state the opposite, proving that it is weak and incapacitated (Edwards and Foley, 1996; Wiktorowicz, 2000; Volpi, 2004; Hinnebusch, 2006). However, this analytical dichotomy could not explain events that occurred in the first half of the 2010s, when amid mass protests in the countries swept by the Arab Spring one could see an amazing variety of non-state actors which demonstrated their ability to unite under democratic slogans.

Judging from the generally accepted UN definition of civil society organization given by the United Nations Development Program (UNDP), this category can only include structures devoid of explicit party and political affiliation and direct ties with specific political forces and movements. However, averaged definitions used for the analysis of social order at a given time were not suitable for studying the development of illiberal civil society. When Civil Society Index 
(CIVICUS) surveys began in Egypt in the early 2000s, it became clear that universal criteria for civil society assessment mismatched Egyptian realities and that the standard definition of civil society as "the arena, outside of the family, the state and the market, where people associate to advance common interests" (CIVICUS, 2005, p. 20) did not work there. Egypt is known for the diffusion of power and civil society, the border between them is tentative and permeable, and NGOs are mostly created by retired or even active government officials and financed from the budget, which has a direct impact on their activities-instead of criticizing the authoritarian regime, they often act as its tool or even mouthpiece (CIVICUS, 2005, p. 20).

Another characteristic feature of countries in this region is that political society and civil society form one whole, which does not fully match the classical model of civil society either. A vivid example is Islamic movements, which, having created their parties and asserted themselves in formal politics, continued to build up an informal network of supporters and various forms of grass-roots activity. Movements such as Hamas, Muslim Brotherhood, Hezbollah, etc., are an example of triune civic engagement (Clarke and Jennings, 2008, pp. 214-239) as they are active simultaneously in political parties/movements, civil society organizations, and various informal structures.

All this, on the one hand, shows that the apolitical concept of civil society cannot be used for understanding and analyzing their modus operandi in the Middle East, where political parties and NGOs should rather be considered part of one whole-a broad coalition of opposition forces (Posusney and Angrist, 2005, pp. 193-194). On the other hand, it leads us to an alternative research strategy and away from the interpretation of civil society as an "area of relationships" to view it instead as an "area of action." Antonio Gramsci's concept (Gramsci, 1971) can be quite helpful in this case as it defines civil society not as a mere sum of NGOs, but as a sphere in which the state exercises its "cultural hegemony." According to Gramsci, the authorities, as a rule, do not rely solely on violence and coercion, but are also concerned with building social harmony. In the Middle Eastern countries, civil society 
acts as infrastructure used by the ruling regime to exercise its "cultural hegemony" by imposing its own vision of the world as normative and generally accepted.

However, there is yet another important function of civil society as a sphere where various systemic and non-systemic movements seek to change the usual status quo and where alternative models of public order are generated-Islamic, secular, anti-globalist, etc. Authorities react to the ideas of social reconstruction differently not only through direct deterrence and suppression, but also through various forms of cooperative or competitive interaction with civil society institutions (Baranovski, 2018, p. 202).

The diversity of roles and forms of civil society in the Middle East requires not only an expanded definition of the concept itself, but also a research approach based on the multiplicity of typological models of both its institutions and relationships within civil society.

Summing up the empirical material on civic engagement in different Middle Eastern countries in the 2000s-2010s and countryspecific features of civil society development recorded in a number of studies (Wiktorowicz, 2000; Hawthorne, 2004; Cavatorta and Durac, 2010; Altan-Olcay and İçduygu, 2012; Mühlenho, 2014), it is possible to outline several basic features of civil society in the region:

- a dynamically changing degree of legal, financial, and political autonomy of civil society organizations from the government and its support.

- a relative and permeable border between the political sphere and civil society, or even its complete absence, a kind of diffusion of "political" society and "civil" society.

- specific institutional substance of civil society, generated by the diversity of informal organizations.

From an institutional point of view, civil society in the Middle East is a constellation of traditional/endogenous institutions, which have emerged out of religious and communal identity and have a long history of existence, and borrowed/modernized structures. From a functional point of view, its institutions may belong to different categories, but 
engage in the same kind of activities. For example, secular and liberal NGOs often work closely with religious associations, but each has its own relationship with the state, a varying degree of independence from the government, and different approaches to assuring its public legitimacy.

The core of "traditional" civil society in the Middle East consists of community and religious organizations, as well as informal or network structures. "Family" and "community" waqfs stand out among them. These are specific social and charitable endowments founded either by authoritative religious figures or by the leaders of specific communities. They are characterized by a certain degree of isolation as they have no need to expand their membership, and by a high level of sociopolitical activity. Such waqfs are fairly widespread in the region. Historically, they rely on the legacy of similar structures that existed in the Middle Ages; functionally, they employ the model of patron-client relationship which is quite common in the region and which continues to exist even in a "strong state." Such structures are often created by retired highranking government officials or well-known politicians. For example, prominent politician and statesman Mohammad Safadi created his own waqf in Lebanon in the early 2000s to implement large-scale social projects in the country. Usually, such organizations are inextricably linked to the founder, which directly affects their activities. If the founder takes a pro-government position, his waqf coordinates its work with the interests of the ruling regime, thus serving to strengthen its "cultural hegemony." If the founder opposes the government, his waqf also engages in opposition activities and can act as its center. Examples of such opposition charities abound in Turkey (Shlykov, 2019).

Confessional community organizations bring together members of specific ethno-confessional minorities (Shia, Sunni, Druze, Coptic, Maronite, etc.), which are usually oppressed by the titular nation or the dominant confession. They can have different forms of organization, including family foundations, territorial public organizations, and traditional communities. Moreover, civil activity statistics in the region for the 2000s and the 2010s indicate that such structures do not cease to exist, but on the contrary, the number of family foundations and 
territorial NGOs keeps growing hand in hand with the expansion of Westernized public organizations (USAID, 2016). Family foundations can carry out religious and charitable activities, help the poor in cooperation with a specific mosque or church, or work as Western-type development funds, engaging in various social programs. Unlike other NGOs, religious community organizations are closely associated with a particular ethnic or religious group and, as a rule, receive minimal external funding, which is good for their image and public legitimacy in the eyes of people.

The segment of Westernized civil society organizations is also quite diverse and includes various types of NGOs (mostly politically motivated), professional and industry associations, as well as informal associations created mainly by young people and students. They are not comparable in terms of their social influence and form of organization. These can be structures directly related to political movements and parties (their key goal is to provide financial and organizational support to a particular party or movement) as well as peculiar proregime NGOs, which in fact are an extension of relevant government institutions but imitate a social and non-state character (quasi-NGOs).

An important place among Westernized NGOs is occupied by development funds that focus on specific issues (education, medicine, or environment) and human rights organizations. Development funds are widespread in the region, some of them have been around for quite a long time, and they have a well-established dialogue with the authorities, while others are in opposition to the government and often openly conflict with the regime. At the same time, most of the funds maintain a neutral position due to their dependence on external financing, which adversely affects their reputation and limits their sociopolitical activities. Human rights organizations make up an even less homogeneous group. These include local institutions providing social and legal support, national structures, and branches of international human rights organizations (Transparency International, Amnesty International, etc.), which have established partnerships with local NGOs. They not only monitor the human rights situation, but also help the relatives of prisoners, address interfaith problems, improve legal literacy, etc. 
Business associations that appeared to be quite active during Arab Spring protests demonstrated a growing influence among Westernized NGOs in the 2000s and the 2010s. The rich experience of conducting mass actions (strikes, collective petitions, etc.) and effective methods of mobilizing supporters, i.e. levers of pressure on the authorities, have turned trade unions into influential civil society actors. For example, in Tunisia, workers' unions were the main driving force in the Jasmine Revolution of 2011 (Naumkin and Kuznetsov, 2012, pp. $140,145)$. Unions of lawyers have great authority in the region. It is no coincidence that the problem of judicial independence was one of the popular slogans during protests in Egypt in the late 2000s (Naumkin and Kuznetsov, 2012).

Informal structures are in-between modernized and traditional civil society organizations and have assumed some features of both. For the most part, these are informal associations of socially active young people. They operate outside the realm of institutionalized civil society and consider legal NGOs opportunistic and controlled by foreign foundations. In the 2000s and the 2010s, youth associations were at the forefront of protests in Egypt, Tunisia, and Turkey, which turned them, according to some sociologists, into "a new 'organic' civic segment of MENA civil society, a socially rooted civic movement distrustful of the global development industry" (Härdig, 2015, pp. 1139-1140). In addition to youth groups, the segment of informal structures includes politically motivated informal associations. Their activists are not united and organized enough to form a viable political party, but they are ready to form a variety of ad hoc coalitions, not only short-term, but relatively long-term ones, such as the Kefaya movement ("Enough") in Egypt or the March 14 Alliance (M14) in Lebanon.

The substantive, institutional, and organizational diversity of civil society in the Middle East not only reflects the heterogeneity of the region and the plenitude of its cultural features, but also exposes problems within civil society itself, which hinder its development no less than the enduring authoritarian regimes do. By summarizing country-specific characteristics of civil society, one can distinguish a number of common features in its development, or at least similarities 
in what sets and limits its course. These limits include the following common aspects: expansion of informal institutions of power ("parallel”/“backstage state"), aggressive construction of identities by various interest groups and the authorities alike (Zvyagelskaya, 2020, pp. 159-198), and toxicity of external sponsorship of local civil society organizations. The fact that civil society in different countries of the region has become a breeding ground for political Islamic movements can be considered an indisputable common feature.

\section{CIVIL SOCIETY CAPTURED BY STATE:}

\section{STRATEGIES OF SUBORDINATION AND DETERRENCE}

In determining the specifics of Middle Eastern statehood, modern researchers name first of all its inclusive and interventionist character ("there is too much state in all spheres of life"), coupled with "problematic legitimacy in the eyes of citizens" (Zvyagelskaya, 2017; Baranovsky and Naumkin, 2018, pp. 185-190). British historian Roger Owen has caustically described this situation as a tough state that wants to seem strong (Owen, 2004, p. 3, 37, 201).

This does not bode well for the development of civil society: undesirable and inconvenient public organizations inevitably come under restrictions and pressure from the authorities. Only those NGOs can be relatively safe that operate in depoliticized areas or are willing to work for the regime and set a direction for the development of civil society that the government considers right. This is how civil society is developing in Saudi Arabia, where a large number of religious charitable organizations lack political ambitions, but have a noticeable influence in the social sphere (Montagu, 2010). The financial and administrative support for NGOs from the Saudi royal family provides the elite with a channel to get feedback from various sections of society, whose socially active members get a way to convey to the authorities their vision of an appropriate social development model. This ensures multilevel interaction between the state and civil society not only through suppression, but also through a search for mutually beneficial cooperation or the development of mechanisms serving the interests of the regime. 
Statistical indicators cannot always adequately reflect the real level of development and the nature of civil society, as borne out by Turkey's experience (Shlykov, 2018). At the end of the 1980s and the beginning of the 1990s, the country saw a boom of public organizations: there were 38,000 of them before the 1980 coup, two-thirds of which were closed by the military, but their number had exceeded 72,000 by the end of the 1990s (TÜSEV, 2011). However, the statistics turned out to be deceptive: numerous associations, voluntary communities, trade unions, etc. had little influence and their role in the public sphere was insignificant. This clearly exposes a fundamental distinction of the illiberal model of civil society. While in the West civil society is characterized by a system of formalized collaborative relationships and obligations, in this case it is informal ties and various forms of "reciprocal relationships" that come to the fore. Civil society in the Middle East obviously requires a different assessment scale with non-quantitative indicators, since in many countries of the region it involves tens of thousands of public organizations and all sorts of social movements that get broad coverage in the media but have a very modest potential for influencing government decisions and policies (Baranovsky and Naumkin, 2018, p. 212).

In the 2000s, the number of NGOs continued to increase in Turkey, exceeding 150,000 by the end of the 2010s (TÜSEV, 2011; TÜSEV, 2019). At the same time, almost 200,000 NGOs ceased to exist for various reasons in the 2000s and the 2010s (TÜSEV, 2019). The ambivalent statistics on civil society institutions can be explained by the fact that Turkey has obviously been going back to authoritarian rule since the mid-2000s (actual monopolization of the media by the state, persecution of political opponents, judicial biasness), which has expectedly made the political and legal climate extremely unfavorable for the development of civil society. At the same time, basic statistical indicators of civic engagement (the number of public organizations, the range of their activities, etc.) did not stop showing positive dynamics even in the 2010s, despite the crackdown and democratic backsliding.

Following Robert Putnam's paradigm, one would think that the quantitative and qualitative growth of civil society in Turkey in the 
2000s and 2010s, recorded by official statistics, should open up broader opportunities for civic participation or at least the emergence of a pluralistic sociopolitical environment. However, Turkey demonstrated the opposite trend in the 2010s: numerous violations of the freedom of speech and assembly, and an obvious departure from the principles of the rule of law (Amnesty International, 2019; HRW, 2016, 2020). The latest State of Civil Society report (CIVICUS) characterized Turkey as a country with a catastrophic civil society situation, likening it to Venezuela and Afghanistan (CIVICUS, 2017, 2018, 2019, 2020).

The paradox of civil society development in Turkey reflects a fundamental task the Erdogan regime faced in the second half of the 2000s when it was seeking to structure the rapidly rising civic engagement campaign in such a way as to make civil society its ally or subordinate it to its interests. Many hybrid political regimes combining elements of democratic laws and procedures with authoritarian forms of government have encountered the same challenge. Unlike classical authoritarianism, competitive authoritarianism does not seek to suppress civil society completely, but instead tries to use it for its own benefit, which creates a bizarre combination of stick and carrot-the suppression and sponsorship of civil society. In Turkey this happened through the diversification of civic engagement and the divergence of civil society. The government's restrictive policy compelled opposition forces to develop alternative forms of civic engagement and protest. Pro-regime NGOs began to rapidly replace repressed public organizations. This was particularly manifest in structures dealing with the family, women, youth, and education, in strict accordance with the set of key conservative-nationalist values proclaimed by the ruling AKP party.

In the 2010s, the Turkish authorities developed a strategy of interaction with civil society, which, on the one hand, envisaged targeted repressions against disloyal activists and organizations, and on the other hand, sought to build alternative civil society that would be most loyal to the regime. The first part of the strategy was implemented using both legal mechanisms ("To my friends, anything; to my enemies, the law") and direct crackdown tactics in the form of blackmail and 
intimidation against those whom the authorities considered to be the main troublemakers.

It was not difficult to establish legal deterrence mechanisms. In the mid-2000s, the AKP government, following EU recommendations, initiated a revision of NGO legislation. This led to the adoption of new and more progressive and liberal laws on dernegi associations in 2004 and waqf foundations in 2008. The new laws repealed many previous prohibitive norms, and significantly facilitated the work of public organizations and their interaction with international structures. All this had a positive effect on the growth of civic and political activity in Turkey. However, at the same time, new laws introduced state control over NGOs: everything from registration and organization of collective events to attraction of external funding came under close attention of the controlling bodies. Moreover, public audit procedures for NGOs in Turkey became extremely confusing and bureaucratic. In fact, restrictions on the freedom of association did not disappear, but adopted a different form.

In the 2010s, as the number of people dissatisfied with the Turkish government's policy grew, effective legislation provided broad opportunities for suppressing civic participation and banning disloyal NGOs. After nationwide protests in the summer of 2013, the use of repressive measures against opposition organizations-regular unscheduled inspections, fines for real and alleged reporting violations, police raids-became part of everyday life. The 2016 coup attempt marked the beginning of even more intense pressure on independent segments of civil society. In addition to regular formal and informal restrictions on NGOs, the government resorted to direct repressions. As the rare opposition media and international human rights organizations stated, a total ban on public events involving critical activists or preventive arrests of their organizers became widespread in Turkey (CIVICUS, 2018). During the state of emergency in 2016-2018, the authorities confiscated the property of several thousand NGOs, many of which were disbanded without even as much as a formal court decision. According to Turkish human rights activists, more than 1,600 NGOs were ceased to exist (İHOP, 2018). Repressions targeted not only 
organizations, but also well-known human rights activists and scholars with an active civic position. Criminal prosecution for critical posts on social networks became commonplace (HRW, 2018).

However, the policy of the Turkish authorities towards civil society in the 2010s was not limited solely to deterrence and repression. In the fall of 2013, shortly after the mass protests, the government announced a national project for the development of civil society (STK Aç1lımı) to be overseen by the Interior Ministry and aimed at "establishing organizational and financial support for a strong civil sector" (\$̧ık, 2013). As part of this project, regular international NGO fairs (Ulusal ve uluslararası STK fuarları) were organized, the participants for which were selected by specialized units of the Interior Ministry in order to separate radicals from "truly volunteer and charitable organizations" (Şık, 2013).

Unlike direct suppression, the strategy of subordination required finer work and an effective system of interaction between the government and civil society. Work proceeded on two tracks: creating public organizations directly or indirectly dependent on the authorities, and taking over or seizing existing NGOs, dernegi associations, waqf funds, etc. In the former case, people from the inner circle of President Erdogan or members of his family were appointed to the newly created NGOs' boards of trustees. In the latter case, the management of public organizations was changed by force or its key functionaries became employed in government agencies. As a result, there emerged a whole segment of NGOs, quite impressive in size, which had some autonomy and freedom of action (in selecting activists, choosing an area of activity), but at the same time were completely depended on the authorities when it came to financing and their public rhetoric. In fact, this new segment of Turkish NGOs served as a tool for implementing government policies, and coordinated its work and public activity with the ruling party. The core of these NGOs was made up of youth and women's organizations, which are considered the main recipients of conservative ideology. In terms of structure, these were vertically integrated organizations, headed either by AKP members or people closely associated with the party, and all activities on the ground from 
recruiting activists to determining an action agenda were strictly regulated (Yabanci, 2019, pp. 285-306). So there emerged mammoth NGOs such as the Turkish Youth Waqf Foundation (Türkiye Gençlik Vakf1 - TÜGVA) or the Women and Democracy dernegi association (Kadın ve Demokrası Derneği - KADEM). In terms of the scope of activity, the number of active members and organizational model, they looked more like corporations. Pro-regime NGOs did not experience any problems going through over-bureaucratized registration and reporting procedures, and most of them were even able to obtain a special legal status that exempts them from taxes and accounting for private donations (IAI, 2017). In return, NGOs close to the government were expected to promote and popularize social projects launched by the AKP, and help foster a favorable public attitude towards unpopular laws or controversial reforms.

In addition to the advocacy role, pro-regime NGOs have assumed a number of structural and systemic functions aimed at remolding the relationship between the government and civil society. These NGOs have clearly divided Turkish society into "us" and "them," thus exacerbating existing social cleavages. This is especially evident in selective human rights activism. For example, pro-regime women's NGOs blatantly refrain from publicly criticizing the government even in high-profile episodes of violence and abuse of women's rights, but openly condemn feminist activities as "culturally alien to Turkey," echoing the AKP rhetoric about the priority of the family rather than public role for women. Even the declared goals of Turkey's largest women's organization KADEM ("increasing the role of women in society and the family to bring up a highly moral new generation of Turks") reveal Erdogan's notorious thesis that men and women are inherently unequal (Çelikyay, 2015) and that women's rights should be based on "gender justice," which is fundamentally at odds with the principle of "gender equality."

The work of pro-regime NGOs has led to the creation of a multilevel and extensive network of patron-client relationships which permeate the entire sector of loyal civil society. An investigation into the December 2013 corruption scandal exposed the involvement 
of such organizations in multimillion-dollar corruption schemes (Hürriyet, 2014) even though pro-regime NGOs openly receive direct and indirect financial support from the government in the amount of tens of millions of dollars (Şahin, 2019). Meanwhile, volunteers, especially in youth organizations, are developing a set of practical expectations for useful connections or good employment. Once engaged with pro-regime NGOs, they get the opportunity to meet and interact with functionaries from the ruling party, prominent media personalities, big businessmen, and leading politicians.

Material concerning a number of other Middle Eastern countries also shows how NGOs not so much build an infrastructure for civil liberties and political participation, as serve as an instrument of state control over society (Wiktorowicz, 2000). In Jordan, each public organization undergoes a mandatory registration procedure at a special state institution that ranks and monitors NGOs. This allows the state to use NGOs to control social activity and to prevent the emergence of "non-systemic" NGOs that are potentially dangerous for the current regime or undermine the interests of elite groups close to power. The organic link between the state and civil society in the Middle East is also manifested in the dominance of representatives of the government and the national elite among NGO functionaries. They are founders, members of the boards of trustees and management councils, and hold key positions in the governing and executive bodies of a significant part of large and influential NGOs. In the 1990s and the 2000s, Egyptian business associations, considered the most powerful NGOs in the country, could influence government policy using their financial and economic resources and ties with senior government officials. At the same time, they did not respond to the aspirations of ordinary citizens but served the interests of the incumbent regime and large and medium-sized businesses (Abdelrahman, 2004). As a result, the most capable civil society institutions were involved in strengthening the current regime, rather than proposing alternatives to the existing social, political and economic order. Other major civil society actorstrade unions and professional associations-being in direct economic dependence on the government, are unable to confront the authorities 
in order to defend group interests, and their opposition is, in fact, pure imitation (Hawthorne, 2004, pp. 3-24).

Obviously, with multifaceted control of civil society institutions in place, especially of NGOs, jokingly referred to as "state nongovernmental organizations," one can hardly expect civic engagement, squeezed into such a framework and directed from above, to increase the social and political responsibility of the government. On the contrary, such NGOs serve to increase the influence of the ruling elites, which use them to impose a certain political and economic discourse on society. So, there is a vicious circle: ordinary citizens have no mechanisms to influence the government, but the government can manipulate civil society institutions.

This being so, national NGOs turn into instruments used to spread state ideology and impose models of sociopolitical development beneficial to the authorities, with politicians publicly speaking of NGOs as "active partners" of the government (this is how Hosni Mubarak referred to Egyptian NGOs in the 2000s [Hawthorne, 2004, p. 12]). Moreover, such a view of NGOs as a convenient tool for solving political problems-disseminating ideology and managing public consensus-is characteristic not only of the government and national elites, but also of opposition forces which use civil society institutions exclusively as an instrument for mobilizing public support, international organizations and extra-regional players.

\section{CIVIL SOCIETY AS A TOOL FOR IMPOSING DEMOCRACY?}

At the same time, civil society in the Middle East attracts increased interest among Western politicians who in pursuit of geopolitical purposes thought it to be quite potent as an instrument with which, using Robert Putnam's terminology, they could "make democracy work." This growing interest in civil society in the 1990s and the 2000s materialized in large-scale support for local NGOs. The underlying logic was quite simple: even in a weak civil society, its institutions will inevitably work towards overcoming "democratic deficit" (Kamrava, 2007, pp. 189-213). As result, a variety of mechanisms were created in several major countries of the region for the purpose of providing 
external financial support to civil society organizations. The United States offered active assistance to Egyptian NGOs, hoping to accelerate economic liberalization in the country with their help in much the same way it had sponsored Palestinian NGOs in the 1990s in a bid to foster a positive public attitude towards the Oslo Accords (Hawthorne, 2004, pp. 3-24). In the 2000s, external support for NGOs in the Middle East became explicitly "instrumental": regional security and actions against the spread of radical Islamism came to the fore (Altan-Olcay and İçduygu, 2012, pp. 168-9).

Donor funding for NGOs in Egypt, Lebanon, Turkey, and other countries of the region was directly linked to specific criteria they were expected to meet and priorities they had to focus on (Altan-Olcay and İçduygu, 2012). For example, recipients of European support in Turkey were expected to commit themselves to liberal values and actively participate in the liberalization of the country for its accession to the EU. However, the monitoring of remarks by representatives of Turkish NGOs that cooperated with EU structures revealed a paradoxical situation. About half of the NGOs that participated in the EU grant projects in the 2000s were not consistent advocates of the "European way of development for Turkey," and only 4 percent intended to "disseminate positive knowledge about the EU" and "promote panEuropean values" through their projects (Zihnioğlu, 2013, pp. 50-71).

Traditional EU methods of realizing the potential of soft power in the Turkish context faced conceptual and functional constraints: low organizational capacity of Turkish NGOs, a large part of which (over 44 percent) functioned as para-commercial structures (TÜSEV, 2015), weak public interest in NGOs, and low participation in socially and politically active NGOs (not more than 10 percent of the population, of which only 6.7 percent engaged on a voluntary basis) (TÜSEV, $2011,2019)$. All this signified the lack of infrastructure needed for implementing civil society support programs in Turkey.

As a result, the policy of donor assistance to civil society institutions in the Middle East has proved to be an equation with many variables, in which the formula for success tested in other countries produces unexpected results in this region. The effect of long-term investments 
in local NGOs aimed at correcting the vector of sociopolitical development towards Western norms and values has turned out to be very controversial. The clearly visible lack of direct correlation between the receipt of donor assistance by specific public organizations and their commitment to liberal values in countries like Turkey is not only a phenomenon characteristic of pragmatic NGOs which willingly accept funding from European organizations but are not inclined to fully support the "European choice," but also an indicator showing the limits of soft power projected by leading Western countries and international organizations. The reason for these limits is not only that civil society has been idealized, but that it has also been viewed as a single entity without due account for the high degree of its polarization and intricately intertwined fault lines within it.

The manipulation of civil society by the ruling political regimes and external donors has turned it into an arena of confrontation between competing political forces such as Islamists and supporters of secular order in Egypt, Turkey, and Jordan, etc. (Cavatorta and Durac, 2010), or between opposing Islamic sects like those in Lebanon (Altan-Olcay and İçduygu, 2012). Moreover, external manipulation of civil society often leads to unpredictable consequences. For example, the division of civil society over its attitude towards Islam and Kemalism and the emergence of concentric circles consisting of different social groups determine not only the conceptual image of civil society in Turkey, but also the attitude of Turkish NGOs towards EU policy. This is why conservative forces lead the way among grantees in supporting the European integration process, as they view rapprochement with the EU as a chance to crack down on their opponents, but at the same time are not eager to build a close partnership with European structures due to differences in values (Baranovsky and Naumkin, 2018, p. 222).

The polarization of social and political relations, which has become one of the hallmarks of Turkey's modern history, has a direct impact on the nature of ties and relationships within civil society. The fragmentation of civil society and the lack of mutual trust among its organizations standing on different political platforms make it extremely difficult for civil society to consolidate its potential and 
generate sociopolitical development from below. The same factors do not allow external forces to achieve the desired result from their tangible and intangible investments in the development of civil society, and lead to soft-power fiascoes.

The broad variety of forms of civic engagement and the diversity of civil society actors in the Middle Eastern countries make it impossible to produce a single development formula or operating model for civil society in the region. What complicates this process further is versatility of civil society itself, which over time can lose some characteristics and acquire new ones. So in identifying the basic set of common features in the development of civil society in the region, the starting point is its remoteness from the liberal model.

Empirical material on Turkey, Egypt, Jordan, Lebanon, and Saudi Arabia reveals different patterns in the use of civil society by the state. Under hybrid regimes, regardless of the degree of democracy or authoritarianism, civil society organizations become part of the toolkit used by ruling elites to consolidate their political influence and economic dominance. Contrary to the usual liberal discourse, which largely idealizes civil society and its institutions, occupying center stage here are factors that paralyze the democratic potential of civil society. In the Middle East, civil society organizations in reality serve the interests of the political elite more than the interests of ordinary citizens, and do not look very convincing as an outpost of liberal democratic values.

There is yet one more feature that fits into this overall characteristic of civil society in the Middle East as illiberal: a highly controversial response to the sponsorship policies of Western countries and international organizations that have undertaken to support NGOs in some countries of the region. The controversial consequences of such attempts at "liberalization from the outside" are quite visible in Turkey, where half of the NGOs participating in the EU grant projects actually turned out to be opponents of European integration.

Finally, another characteristic of civil society in the Middle East is its lack of political agency. The liberal model of civil society directly 
engaged in the process of state-building is turned upside down there. In the Middle East, under hybrid regimes, it is the state that determines the rules of the game, draws the boundaries of activity and dictates the form of civil society in sociopolitical life. Because of these circumstances, reproducing the model of liberal civil society in the Middle East, even in such a Westernized country as Turkey, has proved to be a very difficult task, despite donor assistance and considerable efforts by international organizations, the EU, and the United States. All this clearly shows the limitations of the liberal model of civil society, which cannot be extrapolated into non-Western cultures, where the activity of civil society is not an indicator of effective democratic institutions.

There is still another common feature in the development of civil society in the Middle East, which reflects the similarity of cultural identities of most of its countries where Islam plays an important structuring role. It is quite natural that widespread and very powerful Islamic movements have featured prominently among influential civil society actors in the region. They have well-established mechanisms for mobilizing their supporters and often act outside the sphere of direct state control, that is, they fully meet the criteria of "influential civil society actors." At the same time, they do not function as a catalyst for democratization, since for the most part they are allergic to Western liberalism.

So it appears that the democratic deficit and the weakness of democratic institutions in the Middle East actually stem from the existence of fairly large, multidimensional, and illiberal civil society, which cannot be functionally fit into any one model. Along with the dominance of social organizations dependent on the state, this leads to the preservation and reproduction of authoritarian regimes, which significantly slows down the evolutionary modernization of Middle Eastern societies, while revolutionary changes cannot subsequently find support among fragmented civil society structures. 


\section{References}

Abdelrahman, M.M., 2004. Civil Society Exposed: The Politics of NGOs in Egypt. London: I.B Tauris.

Almond, G.A. and Verba, S., 1963. The Civic Culture: Political Attitudes and Democracy in Five Nations. Princeton, N.J.: Princeton University Press.

Altan-Olcay, Ö. and İçduygu, A., 2012. Mapping Civil Society in the Middle East: The Cases of Egypt, Lebanon and Turkey. British Journal of Middle Eastern Studies, 39(2), pp. 157-179.

Çakmak, C., 2017. The Arab Spring, Civil Society, and Innovative Activism. New York: Palgrave Macmillan.

Amnesty International, 2019. Turkey's State of Emergency Ended but the Crackdown on Human Rights Continues [online]. Available at: <www.amnesty. org/> [Accessed 1 February 2021].

Baranovsky, V.G. and Naumkin, V.V. (eds.), 2018. Blizhny Vostok $v$ menyayushchemsya globalnom kontekste [The Middle East in the Changing Global Context]. Moscow: IV RAN.

Buttigieg, J.A., 2005. The Contemporary Discourse on Civil Society: A Gramscian Critique. Boundary 2, 32(1), pp. 33-52.

Carothers, T. and Brechenmacher, S., 2014. Closing Space: Democracy and Human Rights Support Under Fire. Washington: Carnegie Endowment for International Peace.

Cavatorta, F. and Durac, V., 2010. Civil Society and Democratization in the Arab World: The Dynamics of Activism. New York: Routledge.

Chandhoke, N., 2001. The 'Civil' and the 'Political' in Civil Society. Democratization, 8(2), pp. 1-24.

CIVICUS, 2005. An Overview of Civil Society in Egypt: Civil Society Index Report for the Arab Republic of Egypt. Cairo: Center for Development Studies. Available at: <www.civicus.org/> [Accessed 1 Feb. 2021].

CIVICUS, 2018. Unending Restrictions on Civic Freedoms. [online] 2 May. Available at: $<$ monitor.civicus.org/ $>$ [Accessed 1 February 2021].

Cohen, J.L. and Andrew, A., 1992. Civil Society and Political Theory. Cambridge: MIT Press.

Çelikyay, A.E., 2015. Kadın Hareketi ve KADEM [Women's Movement and Women and Democracy Association]. KADEM [online], 7 June. Available at: $<$ kadem.org.tr/ $>$ [Accessed 1 February 2021]. 
Diamond, L., 1994. Rethinking Civil Society: Toward Democratic Consolidation. Journal of Democracy, 5(3), pp. 4-17.

Edwards, B. and Foley, M., 1996. The Paradox of Civil Society. Journal of Democracy, 7(3), pp. 38-52.

Edwards, M., 2005. Civil Society. The Encyclopedia of Pedagogy and Informal Education. Available at: <www.infed.org/association/civil_society.htm> [Accessed 1 February 2021].

Edwards, M., 2014. Civil Society. 3rd edition. Malden: Polity Press.

Gramsci, A., 1971. Selections from the Prison Notebooks of Antonio Gramsci. New York: International Publishers.

Clarke, G. and Jennings, M. (eds.), 2008. Development, Civil Society and FaithBased Organizations: Bridging the Sacred and the Secular. New York: Palgrave Macmillan.

Härdig, A.C., 2015. Beyond the Arab Revolts: Conceptualizing Civil Society in the Middle East and North Africa. Democratization, 22(6), pp. 1131-1153.

Hawthorne, A., 2004. Middle Eastern Democracy: Is Civil Society the Answer? Carnegie Papers: Middle East Series, 44, pp. 3-24.

Hinnebusch, R., 2006. Authoritarian Persistence, Democratization Theory and the Middle East. Democratization, 13(3), pp. 373-395.

HRW, 2016. Silencing Turkey's Media. Human Rights Watch [online]. Available at: <www.hrw.org/> [Accessed 1 February 2021].

HRW, 2018. Turkey: Crackdown on Social Media Posts. Human Rights Watch [online], 27 March. Available at: <www.hrw.org/> [Accessed 1 February 2021]. Hürriyet, 2014. Charity NGO Counting Turkish PM's Son as Board Member Received \$99,999,990 in Donations: Deputy PM. Hürriyet Daily News [online], 10 April. Available at: <www.hurriyetdailynews.com/> [Accessed 1 February 2021].

IAI, 2017. Trends in Turkish Civil Society. Istituto Affari Internazionali, 2017 [online]. Available at: <www.iai.it/> [Accessed 1 February 2021].

İHOP, 2018. 21 Temmuz 2016-20 Mart 2018 Olağanüstü Hal Uygulamaları Raporu [21 July 2016-20 March 2018 State of Emergency Implementation Report]. Insan Hakları Ortak Platformu [online]. Available at: <www.ihd.org. $\operatorname{tr} />$ [Accessed 1 February 2021].

Kamrava, M., 2007. The Middle East's Democracy Deficit in Comparative Perspective. Perspectives on Global Development and Technology, 6, pp. 189-213. 
Posusney, M.P. and Angrist, M.P. (eds.), 2005. Authoritarianism in the Middle East: Regimes and Resistance. Boulder, CO: Lynne Rienner, pp. 193-218.

Lewis, D., 2013. Civil Society and the Authoritarian State: Cooperation, Contestation and Discourse. Journal of Civil Society, 9(3), pp. 325-340.

Montagu, C., 2010. Civil Society and the Voluntary Sector in Saudi Arabia. Middle East Journal, 64(1), pp. 67-83.

Mühlenho, H., 2014. Funding Democracy, Funding Social Services? Journal of Balkan and Near Eastern Studies, 16(1), pp. 102-118.

Naumkin, V.V., 2015. Deeply Divided Societies in the Middle East: Conflict, Violence, and Foreign Intervention. Vestnik Moskovskogo universiteta. Seriya 25, 1, pp. 66-96.

Naumkin, V.V. and Kuznetsov, V.A. (eds.), 2012. Blizhny Vostok, Arabskoye probuzhdeniye i Rossiya: chto dal'she? [The Middle East, Arab Awakening and Russia: What Next?]. Moskva: IV RAN.

Norton, A.R. (ed.), 1995-1996. Civil Society in the Middle East. Vol. 1, 2. Leiden: Brill.

Owen, R., 2004. State, Power and Politics in the Making of the Modern Middle East. London: Routledge.

Putnam, R.D., 1993. Making Democracy Work: Civic Traditions in Modern Italy. Princeton: Princeton University Press.

Rosenblum, N.L. and Post, R.C., 2002. Civil Society and Government. Princeton: Princeton University Press.

Shlykov, P., 2018. The "Turkish Model” in Historical Perspective. Russia in Global Affairs, 16(2), pp. 34-59.

Shlykov, P., 2019. The Secularization and Desecularization Nexus in the Turkish Context: What Is Behind? Politics and Religion Journal, 13(2), pp. 199-236.

Şahin, İ., 2019. İBB hangi vakıf ve derneğe ne kadar yardım yaptı? [Which Foundation and Association and How Much Did Istanbul Metropolitan Municipality Help?]. Sözcü [online], 23 April. Available at: <www.sozcu.com. tr/> [Accessed 1 February 2021].

Şık, B., 2013. 'Çapulcu' gelmesin vay vay [Don't Let the Ravager Come]. Cumhuriyet [online], 19 November. Available at: <www.cumhuriyet.com.tr/> [Accessed 1 February 2021].

Tarrow, S., 1996. Making Social Science Work Across Space and Time: A Critical Reflection on Robert Putnam's Making Democracy Work. American Political Science Review, 90(2), pp. 389-397. 
Tocqueville, A., 2000. Democracy in America. Chicago: University of Chicago Press.

TÜSEV, 2011. Türkiye'de Sivil Toplum: Bir Dönüm Noktası [Civil Society in Turkey: A Turning Point]. İstanbul: TÜSEV Yayınları.

TÜSEV, 2015. Sivil Toplum İzleme Raporu. 2013-2014 [The Monitoring Report of Civil Society. 2013-2014]. İstanbul: TÜSEV Yayınları. Available at: <www. tusev.org.tr/> [Accessed 1 February 2021].

TÜSEV, 2019. Monitoring Matrix on Enabling Environment for Civil Society 2019 Turkey Report [online]. Available at: <www.tusev.org.tr/> [Accessed 1 February 2021].

USAID, 2016. The 2016 Civil Society Organization Sustainability Index for the Middle East and North Africa. Washington: US Agency for Int. Development (USAID). Available at: <www.usaid.gov/> [Accessed 1 February 2021].

Volpi, F., 2004. Pseudo-Democracy in the Muslim World. Third World Quarterly, 25(6), pp. 1061-1078.

Wiktorowicz, Q., 2000. Civil Society as Social Control: State Power in Jordan. Comparative Politics, 33(1), pp. 43-61

Yabanci, B., 2019. Turkey's Tamed Civil Society: Containment and Appropriation under a Competitive Authoritarian Regime. Journal of Civil Society, 15(4), pp. 285-306.

Zihnioğlu, Ö., 2013. European Union Civil Society Policy and Turkey: A Bridge Too Far? New York: Palgrave Macmillan.

Zvyagelskaya, I.D. (ed.), 2020. Blizhny Vostok: politika i identichnost' [The Middle East: Politics and Identity]. Moscow: Aspekt Press.

Zvyagelskaya, I.D., 2017. Sovereignty and Statehood in the Middle East-the Unbearable Fragility of Being. Outlines of Global Transformations: Politics, Economics, Law, 10(2), pp. 97-109. 